\title{
Interview with Composer George Tsontakis
}

$\mathrm{T}$ This interview for the journal ICONI, taken by Dr. Edward Green, Professor at the Manhattan School of Music, is with one of the leading composers of the United States, George Tsontakis. A professor at Bard Conservatory of Music, he is the recipient of numerous awards for his work, including the prestigious Grawmeyer Award for his Second Violin Concerto. Professor Tsontakis' work - nearly all of it commissioned - is wide-ranging in terms of genre, imaginative in its orchestrations, and always strongly emotional. Included in this interview are discussions of some of the biographical background to a number of his major pieces, including The Past, The Passion. Among the subjects discussed is the meaning of "concerto." Several of his concertos and concerto-like compositions are specifically discussed in this interview, including Man of Sorrows (piano), and Sonnets (English Horn). The interview also touches upon his relations with two important American composers of earlier generation: George Rochberg, and Roger Sessions - who had been Tsontakis' teacher of composition at Julliard.

Это интервью для журнала «ИКОНИ» доктор Эдвард Грин, преподаватель Фонда эстетического реализма в Нью-Йорке, профессор Манхэттенской школы музыки, взял у одного из ведущих композиторов США Джорджа Цонтакиса. Профессор Бардовской Консерватории музыки, он является лауреатом премий и обладателем многочисленных наград, в том числе престижной награды Grawmeyer за Второй концерт для

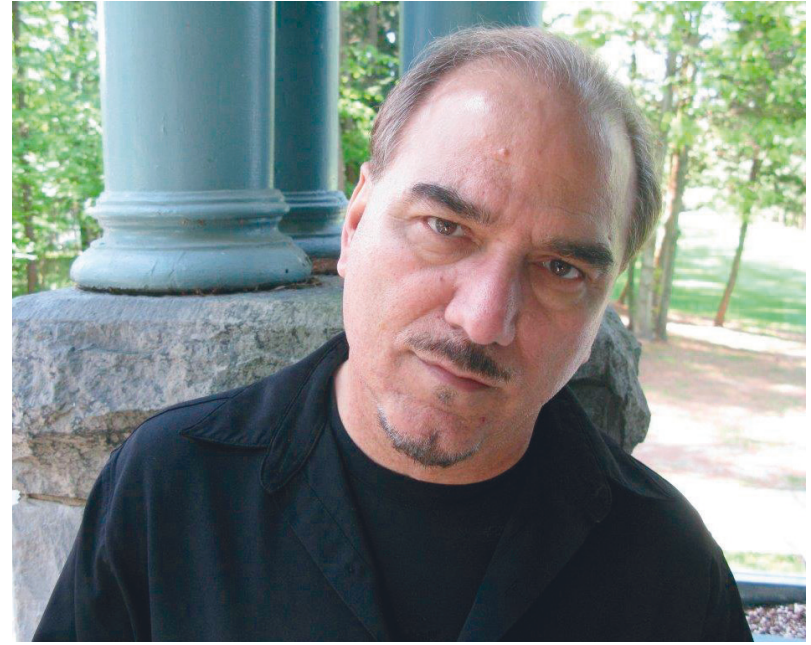

Photo 1. George Tsontakis Photo Credit: Mel Rosenthal

скрипки с оркестром. Профессор Цонтакис почти всегда пишет на заказ. Его работы разнообразны по жанрам, образны в оркестровке и всегда необычайно эмоциональны. Публикуемое интервью представляет собой обсуждение некоторых биографических предысторий к ряду его главных произведений, включая «Прошлое», «Страсть», рассуждения о значении жанра концерта на примере нескольких концертов композитора и оценка концерта как произведения. В интервью обсуждаются в том числе «Человек скорби» (фортепиано) и “Сонеты» (английский рожок). Разговор также коснётся его отношений с двумя известными американскими композиторами более раннего поколения: Джорджем Рочбергом и Роджером Сешнсом, который был учителем композиции Цонтакиса в Джульярде. 
Edward Green: It may seem surprising to begin an interview by suggesting readers visit another interview with you, but that's what I'm about to do! — suggest that, at some point, the readers of ICONI take a look at the marvelous, wide-ranging, biographically juicy, insightful, and extended interview Frank Oteri gave for the site New Music Box. Here's the link:

\section{https://nmbx.newmusicusa.org/ george-tsontakis-getting-out-of- my-introvertism/}

What I want to ask is how you felt about the title "Getting Out Of My Introvertism" — did you feel it skewed the picture of who you are as a person and as a composer? Or was it solid insight? One reason I ask is that, as I've come to know your work, I notice that your multi-movement pieces tend to start with something either on the slow, or on the "atmospheric" side - and you reach faster, and strongly rhythmic music later.
Which does seem, in a general way, to correspond to the title Frank Oteri gave. To cite one example: Anasa, which ends with a marvelous quasi-Chasidic Niggun, "BirZirk!” In a recording I heard, David Krakauer plays it to a Fare-Thee-Well.

\section{Anasa: III (Bir-Zink!) \\ https://www.youtube.com/ watch?v=EXuiRETOipo}

And then there are many pieces that move towards great outward energy - such as Unforgettable, with its middle movement, "Leapfrogging", only to turn, for lack of a better phrase, more "inward" in the third. Or your Third Piano Quartet, which, with its four movements, at first seems to take a clear Baroque "Sonata da Chiesa" design Slow, Fast, Slow, Fast - yet in its last minutes, concludes in a slower, more thoughtful manner.

So - what are your impressions of all this? Is this something of a trend in your

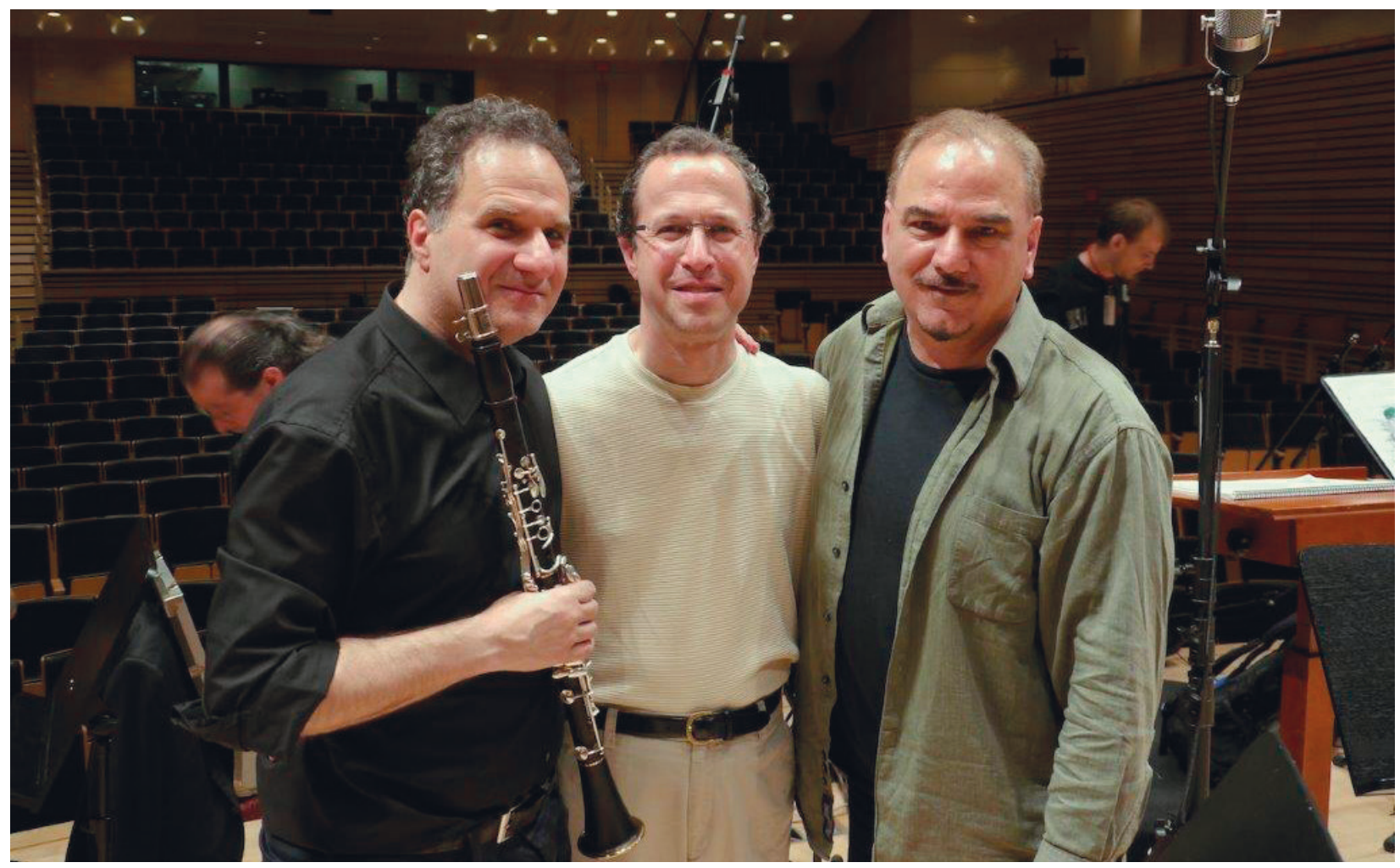

Photo 2. With David Krakauer, clarinet, and David Alan Miller, conductor, Albany Symphony Photo Credit: George Tsontakis 
music? And if so, what do you think it means in terms of your over-all artistic vision?

George Tsontakis: I don't know where they got "Getting Out Of My Introvertism" as the title. If anything, I'm trying to stay IN my Intorverism, so, no: it doesn't really identify me currently. Maybe they felt I was trying to get out of it for their interview, which I thought was quite good.

Yes, I guess that many of my works begin with slower movements, as if to warm up the piece a bit before pumping in the adrenaline. But not all. It could be as simple as my thinking that if I begin what is to be a longer-form work, that is, 20 minutes or more, I am thinking that starting with fast music will be too much work and need too many measures. So I may not write some fast music until the work demands some contrast for "relief" from slow or moderate.

Tying your two questions together I am thinking that perhaps in any such work of mine that starts slowly and softly and builds, that it is the piece itself (if I may personify it) that is working to get out of its introverted shell, eventually opening up. But for that, I'll have to ask those pieces sometimes - at least the ones that remain on speaking terms.

Edward Green: I was very taken by your recent orchestral work Sonnets, which does seem to be, in all but title, a concerto for English Horn. It's out now on Naxos, on an album of commissions by the Boston Symphony, one of which is your lovely and strikingly orchestrated piece. But I'm not going to ask directly about its vivid musical colors, though please feel free to comment on that, if you like. What I'd like most to know is how you approached the idea of "setting" Shakespeare - yet without using his words. To me, this is a fascinating question of aesthetics. Prokofiev, in Romeo and Juliet clearly gave amazing musical justice to Shakespeare's poetic drama, but no words were quoted. Ellington (and Strayhorn) attempted a kind of musical justice to sonnet form, and to portraits of four of Shakespeare's major characters, in the "Sonnets" in their album Such Sweet
Thunder. (I like the Prokofiev a good deal more, by the way.) They went so far as to create melodies which followed the syllable count, and the line count, of the standard Shakespearean sonnet.

So my question is: What was your approach? Some things in the way of general appropriateness are clear enough: the thoughtful and atmospheric setting of the opening movement "When to the sessions of sweet silent thought" (Sonnet 80). Also the "time-keeping" beat that comes forth as the second movement begins (Sonnet 12): "When I do count the clock that tells the time." But I get the impression there is much more happening in the music - a good deal more thought you gave to how to be fair to Shakespeare's poetry while not quoting it directly one bit. Can you fill us in about that?

\section{Sonnets: II (Sonnet 12) \\ https://www.youtube.com/ watch?v=PrxOYBElSb0}

George Tsontakis: In response, I am first thinking about something that Schoenberg was said to have thought about his setting of The Book of the Hanging Gardens, poems by Stefan George. That is: that he composed them less on the basis of the literal meaning but more (to the effect of) "on the sound of the poetry, the words alone." And one might keep in mind that I had composed my Four Symphonic Quartets, based on TS Eliot's great poem (but without text), decades before. Same deal.

With Sonnets, I absorbed the essence of the poem that resonated for me personally and then ... let it rip! I am completing my Portraits by El Greco (Book II) any day now. And so it is with the paintings by Theotocopoulos I chose to set. Poetry or image, either one is re-projected from a personal angle and, no doubt, from a distinct but limited vantage point. In other words, I don't think too much about it; I feel and write, trusting that the listener can always go to the source material and fill in the blanks for themselves. It's just best for them not to look to me for all the 
answers, as some seem to do. I say, go find your own interpretation.

Edward Green: One of your most important works, in my opinion, is Man of Sorrows from 2005, a very unique piano concerto. It seems to me that the titles you gave to the six movements can't be read any other way than as an attempt on your part to come to grips with the meaning of the drama of the life of Jesus. At the same time, the references to Beethoven, technically and otherwise, are everywhere to be heard.

Now, I don't know if you know the book A Musical Pilgrim's Progress (1943) by J. D. M. Rorke in which he traces his own growth - as an amateur musician - in terms of first appreciating Chopin, then Bach, and finally Beethoven. But in that book he very movingly relates Beethoven and Christ. It seems to me, in your own way, and strictly through the language of music, you are doing something similar; were motivated by something similar. Am I on to something - or no?

George Tsontakis: You are in not only to something, but to "the thing." It's important to know that my conception of a piece often includes the performer who asked for the piece in the first place. For example, writing my Second Quartet for the Emerson Quartet, which was commissioned by the Chamber Music Society of Lincoln Center in 1984, I literally envisioned the "Emerson Fab Four" walking onto the stage at Tully Hall, sitting down - then playing. Playing what? Playing something that suited them and something I would feel excited hearing.

With MOS, it was the close personal relationship I had developed with Stephen Hough, who had recorded my Ghost Variations and performed them in nearly every prestigious concert hall in the world. We are both open-minded and universal Christians (I believe he would accept my description; that is, more in the sense of a Messaien or Teilhard de Chardin than an Evangelical type.) Stephen is a convert to Catholicism and a mystic, as far as I'm concerned. And yes, Beethoven as a conduit who I believe reflected a similar spiritual sense as Jesus, indirectly - although we really don't know what was going on in his "introversion" since those types don't always spill the beans about their inner prompting.

I miss my good friend Christopher Rouse and am always lifted by his brief but affecting comment about my work penned for my Four Symphonic Quartets CD - part of it being: “...his profound spiritual impulse, even when it does not purport to examine spiritual matters. His work touches the heart in a deep and personal way." If a smidgeon of that true for my own modest efforts, then a hundredfold for Beethoven. The mechanics within Man of Sorrows - the "Diabelli" (diabolis) variation, "Muss Es Sein," whole tone scales, and the multiplicity of "Threeness" - are all related to the Man of Sorrows idea. Many don't get it, don't want it or don't want to know about it but that's what makes the world so interesting.

Edward Green: Following through on the last question, I don't know how deep, orthodox, or even existent your religious convictions are. But it does seem you often turn towards religious themes, sometimes even to previously existing sacred music, to help give form to your emotions and to your musical expression. I'm thinking of the 1987 piece - a surprising and wonderful thing, in my estimation - The Past, The Passion. I gather it's something of a portrait of your father, or at least an attempt to give him a musical memorial. And there, in the heart of it, is the great "Passion Chorale" which plays such a crucial role in Bach's St. Matthew Passion. Maybe the piece is too personal, means too much to you, to ask you to comment directly - that is, on the emotional impetus that made for it, and how you gave that depth of feeling the musical shape you did. But if you could comment, I would be grateful, and I imagine the readers of ICONI would be, as well.

The Past, The Passion ("The Passion") https://www.youtube.com/watch?v= LUt-t5FJHf0 
George Tsontakis: I actually had to grab the liner notes from the St Paul Chamber Orchestra CD on $\mathrm{KOCH}$ for recall on that 33 year old work. I should not have had too since only a couple of years ago, I enlarged the work from the original 14 player version to full orchestra, as premiered by the Albany Symphony. I recall that somehow, the "herzlich tut mich verlangen" chorale somehow entered into the work "along the way" but am a bit cloudy on how my father fit in - most likely due to my remembrances in "The Past," the antecedent of the work.

It happens that, in general, I try to "forget" the last piece I wrote in order to "move on" to the next, knowing full well that much of that last work, along with the lot of the works preceding it, will bleed through my subconscious anyway. Similar to the way in which I try to remember a dream I had upon waking - by not "trying" to remember, but instead, emptying my mind as completely as I can. It seems to happen, that if the dream was vivid and important enough, it will bleed through and make itself present. As far as my possibly being "religious," there have been manifestations that have aligned for me in the past that have enhanced my wonderment concerning otherworldly phenomena. The best way to describe it is, like one who is born with strong intuition, or talent for something, I was born religious. Simply put, while I acknowledge that in the practical realm two plus two equals four, I have had more interest in the mystical realm where two plus two equals five. In my works I often feel as though I am searching for that extra "one", to make the whole become enhanced, enlarged and empowered, and become a five.

Edward Green: As readers of this series of composer interviews know, my own perspective on music is grounded in what I learned from the great American philosopher Eli Siegel. One of the central principles of Aesthetic Realism, the education he founded, is this: "In reality opposites are one; art shows this.” He also explained - and the kindness and precision of this are revolutionary - how life and art are truly related: "The resolution of conflict in self is like the making one of opposites in art." Now, some composers are more consciously philosophic about their work; others, less. I don't know the degree to which you think about your own work - on a technical level, too - in philosophic terms. So, I'm very interested in how, as you create your music, you might perhaps be thinking about the drama of opposites. Can you comment on this?

George Tsontakis: I know what you're getting at, Ed. I'll try the best I can to give you my view. Generally, I prefer to think of the forces I would seek to utilize and develop in a work or movement as not so much absolutely opposing each other, but as obliquely opposing — that is, setting up a dialectic or, as is the traditional "Classical" term, simply "contrasting."

But a very special brand of contrasting for sure, and therein lies the art: that is, one's ability to chose wisely, or find by sheer luck a unique potential in those seemingly unrelated ideas. (I think of George Rochberg's comment in his generous notes to the recording of my 3rd and 4th quartets: “...he has the 'luck' of having concrete musical ideas that the ear can perceive and the mind can hold in memory.") Add to that, having the luck or apt perception to find forces (or musical ideas, for lack of a better term) which are somehow wed and that lead to an inevitable, tangential destiny. But: Shhhhh! - the listener is not supposed to know that - not at first.

String Quartet \#3, Coraggio; mvt. 2 ("Misterioso")

https://www.youtube.com/watch?v= BjXTso1jON4

As the work then develops and those forces begin to "play" and spin, the expectation of their dramatic relationship begins to be perceived in the listener. It is all about how Expectation is built in - with a capital E. That's something I find so lacking 
in so much contemporary music. There are myriads of fascinating gestures, hoards of ingenious textures and stacks of startling attacks, for example - but without the sense of linear Expectation, frankly it bores me to tear. And particularly when I sense the composer trying desperately to be not just modern, but original. I still maintain that outside of our individual and often nuanced additions to the repertoire, paltry few of us are truly innovators and most of us mop up, sometimes exquisitely, between revolutions. Innovators come but a few times a century (and they are usually French).

It is wholly true that I have always found it necessary (again, I was born this way) to travel two distinct, disparate but parallel roads, in order to fulfill my personal destiny; whether it be noticed or not. Within that voyage (which I have enjoyed greatly, along the way, as Cavafy's "Ithaca” admonishes us to do) composing has been only a part of the whole, but perhaps the journey's most tangible achievement.

Edward Green: Continuing, a bit, with the last question: you've written many concerti. Some directly titled that, others in all but name. And you won the prestigious Grawemeyer Award for one of them, yes?

George Tsontakis: Yes, the Second Violin Concerto. Steven Copes premiered it.

Edward Green: And if a concerto symbolizes anything, it seems to me, it has to be the drama of the self and community - whether that community is conceived of in terms of other people, or nature. (My Piano Concertino, for example, is basically designed along the lines of the second possibility; my Sax Concerto, the first.) It happens that the most important book of philosophy published in our lifetime has this drama of opposites in its very title: Self and World by Eli Siegel - and it was through studying this great work that I came to realize how crucial these opposites are in every concerto. So - have you had thoughts along these lines? Of the inherent, or natural symbolism of concerto form? I'd love to know how you see it, since your concerti, in my estimation, are some of the very best of recent decades. Including the marvelous Third Violin Concerto you recently wrote for Gary Levinson - a friend, by the way, we have in common.

George Tsontakis: I try not to think too much: burden myself about the past uses of an idiom, although like my "dreams" analysis, above, it is bound to creep in. To me, the term "concerto" simply means a work where, usually, one instrument is featured above the rest and except for piano and harp, that player stands up in front of the orchestra. Like an architect, I am charged to make the best use of the forces that I can muster.

\section{Violin Concerto \#2, “Gioco” ("Games”) \\ https://www.youtube.com/ watch?v=leOt15vdEns}

Owing to the fact that each of the many soloists I have composed such pieces for requested the work from me and worked personally to secure a commission for it (great players like Levinson, Sheena, Hough, Cho Liang Lin, Glennie, Copes and others as great but perhaps lesser known) the most important thing to me has been to respond to them with a damn good piece and with something outstanding for them to play. After all, they chose me out of so many possible composers! I must answer in kind, as they are family: "my kind of people." Over several years, Rob Sheena, the amazing English Horn principal of the Boston Symphony complied a huge list of terrific composers, internationally, after Levine had offered him a BSO commission for a concerto. His confidence in me out of the blue (I had never heard of him) moved me greatly and lifted my spirits. It was a part of those spirits and more, which I felt I had to give back. As it turns out, Shakespeare helped deliver the goods!

To complete my answer to your question, sometimes there's a narrative involved, sometimes the notion is more abstract. Usually, my soloist does not play "the hero" 


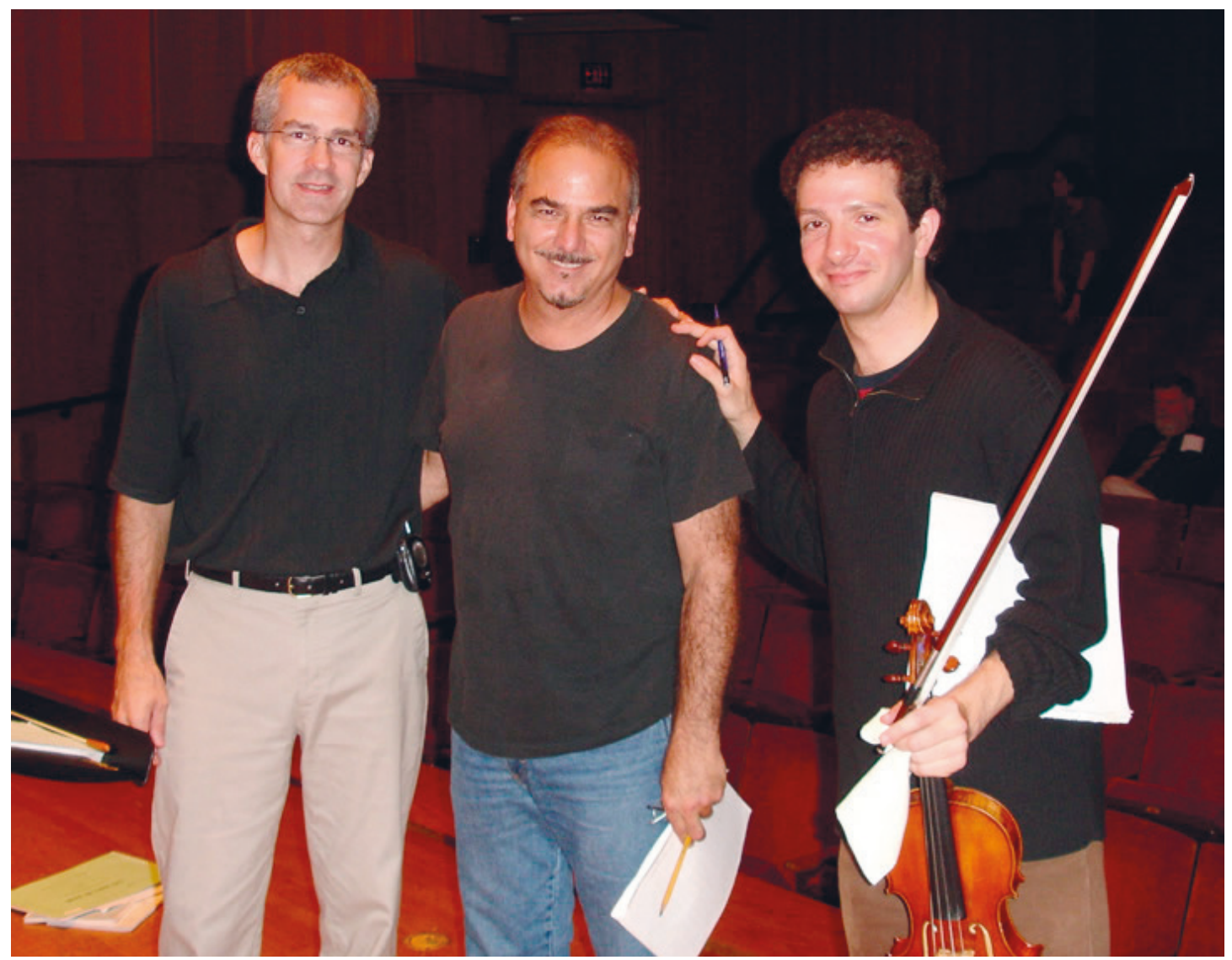

Photo 3. With Steven Copes and conductor David Dzubay, Jacobs School of Music, Indiana University Photo Credit: Yoomi Paick

(or God forbid, showboat) but rather plays a musician of heart who acknowledges the fine musicians around him/her that are sitting down. Engaging them - or even enticing them - to be an integral part of the musical landscape.

Edward Green: Your musical influences practically "cover the waterfront." I like that, and respect it. I hear Messiaen, Bach, Ravel, Beethoven - and so many others. Many people think to be affected by other people deeply is to lose one's own individuality. Obviously, you don't. So, would you say something about this? I ask because it seems to me the more widely and deeply one is stirred by the meaning of other people - musically, for sure, but not just limited to that - the stronger one is, and the more free one is to see what it is one truly feels for oneself. Do you agree? And while we are on the subject, since this interview is for a Russian-based journal, could you comment, along the way, on what Russian composers have meant to you? And if you want to include Russian thinkers, authors, etc. - go right ahead.

George Tsontakis: As they say: "You are what you eat." And I would add that it's the healthier foods that make one strong. I don't know about Ravel; perhaps at times, when my music rolls and flows a certain way with ostinatos and the like. But I would replace him with Debussy and conjecture that my strongest linear heritage is Berg (by way of Schoenberg), Beethoven, Debussy and Messaien, with an occasional "local" tip from Ligeti-and then, by way of all of them, back to Bach.

I think that of the 20th Century Russians, the purest is Rachmaninoff, in the same way that Tchaikovsky is the purest of the 
Russian Romantic composers. I "perceive” no techniques of composing with Rachmaninoff and Tchaikovsky, only pure melodic and harmonic invention, as if the most obvious layers are so damn good, who needs the distraction of "impressive" compositional craft? I prefer the wider color palette of Prokofiev over Shostakovich, who is indeed a great composer, but his constant darkened brooding and what I feel his attempts to manipulate me to brood along with him is eventually, somewhat oppressive. When I speak to audiences about him I relate that "when Shostakovich hits a minor chordthat's the happy part!" Or alternately, I describe his music as "minor and worse." It's just a matter of taste and of temperament. I also find his stringent rhythms and symphonic movement intentions and shape very 19 th Century, but with more piquant dissonance. It's kind of new wine in old bottles, but yeah, he is a master of his idiom and reaches people.

I learned through Messiaen (who is profound without the use of any minor sonorities!) that deep pastilles and flowing through the bar-line trumps the heavy downbeat and darkened sonorities every time.

Edward Green: Now, a question, and it may arise from my less than exhaustive sense of your musical output. I don't hear so much influence in your music of the American vernacular/pop tradition. That is, I don't hear much jazz, or rock-and-roll. Let alone "The Great American Songbook" - Gershwin, Berlin, Rodgers, etc. Is this true? Or, as very likely is the case, is it just that I need a broader sense of your output?

George Tsontakis: Hmmm, there are so many passages of Rock "DNA," especially The Beatles, almost all of which I realized after I've composed a passage. Jazz is the basis for the last movement of my trumpet "concerto" True Colors as well as an extended movement of Eclipse, not to mention much of my Second Piano Quartet.

$$
\begin{aligned}
& \text { Eclipse (II) “Hyperactive” } \\
& \text { https://www.youtube.com/ } \\
& \text { watch?v=B8kWCK_rFa8 }
\end{aligned}
$$

Rochberg has referred to my identifiable and memorable seminal material (fragments, motifs, gestural phrases) as musical DNA. As we know, a miniscule sample of DNA tells a much larger story and is a remarkable thing indeed. I find myself implanting snippets of the DNA of other composers but most often, too small a sample to be out and out recognized - and usually I realize it after the fact, as I mentioned. My thought is that they are powerful and timeless "discoveries" that I grow and embellish in another direction. And I use them in the oddest of places, where one would not suspect they are planted.

I'll give you one small example since you mention Richard Rodgers. The last utterance of Sonnets, which comes after 24 minutes of "Shakespeare" is a direct quote from "This Nearly Was Mine" from South Pacific; the English Horn intoning the last resolving note all alone. To me, this summed up in a tiny capsule, the essence of much of what the Sonnets had to say.

Edward Green: That is an affecting thing to know.

George Tsontakis: By the way, imbedded in the second movement of my Clair de Lune (ironically, since it's an homage to Debussy) are a few measures of Pierrot Lunaireverbatim - note for note and same instruments (except muted horn intones the vocal part; that's a hint). I love the fact that not one wiseguy musicologist nor critic, who love pointing out obvious references, has ever heard what was a true quote!

Edward Green: While your work is unique, you probably have a sense of "kindred spirits." As I think all composers do. So, who among recent composers (American or otherwise) do you feel most sympatico with? One person who came to my mind was George Rochberg - who, I know, wrote the really lively linear notes to the New World Record CD which contains your Third and Fouth String Quartets. Am I right about that? And are there others you might mention?

George Tsontakis: Abstractly, Messiaen, who I was lucky to hear live in a concert with his wife, Lorid, at Cornell. I think it was 1971 


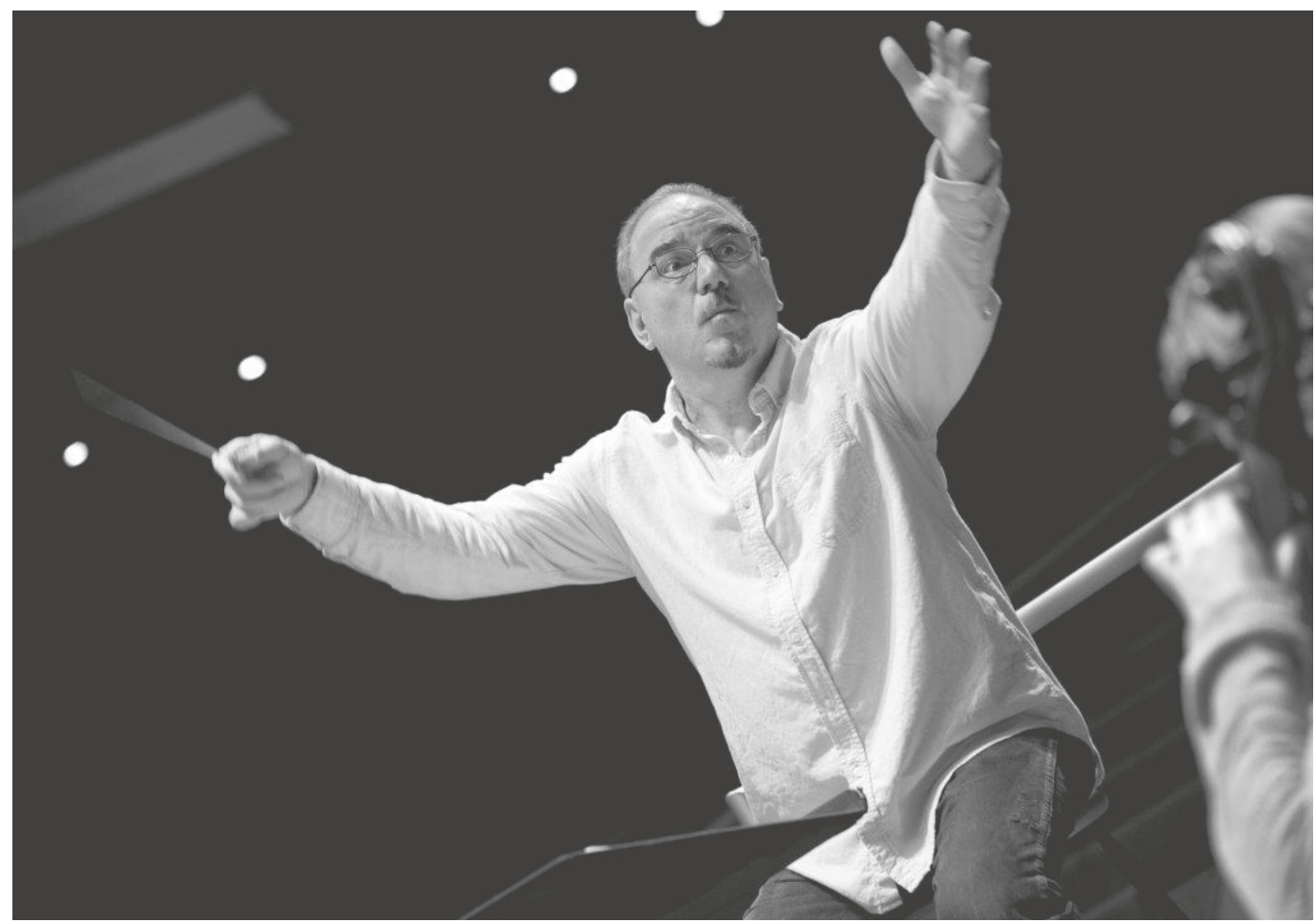

Photo 4. Conducting the Bard Conservatory Orchestra Photo Credit: Yumiko

or 72. I've already mentioned Chris Rouse and I felt we were most certainly kindred spirits. Musically, Chris on the larger than life side of kindred and me a more nuanced and subtly submerged side. David Del Tredici and Corigliano as kind of peripheral "heroes" since they cleared so much of the brush blocking partial-tonality, so I was able to return to "primary and secondary tonal colors." Ironically, not so much Rochberg musically, but personally; he was another hero and so great to me.

Above all, it was Sessions, who was my sole "confidence" in the darker, less optimistic moments along the way. I learned very early that the only difference between a 22 year old and a 77 year old was a physical one. Some of his amazing and unexpected comments he made to others "behind my back" (and happily) came back to me and bolstered me when I most needed it. One encouraging comment by RS meant more to me than a compendium of all the awards in the world.
Edward Green: It strikes me that, taken as a whole, you are more of an instrumentallyoriented composer than vocal. It's not that you've avoided the voice entirely; hardly. But I think of a person I admire very much, Duke Ellington, who plainly was more at ease, and felt more deeply at home with the greater abstraction instrumental music provides by its very nature. So many of his songs, as I'm sure you know, actually began as purely instrumental pieces, to which (sometimes a good deal later) words were added by another person. Would you like to comment on this? Both in a biographical sense, but also in a wider, more philosophic sense? Because it does seem to me the question of word-music relations is a tremendously profound one, as is the question brought up more obviously by purely instrumental music: namely, What Does Music Mean? Clearly, music to you is hardly an exclusively, or even a primarily, mathematically-abstract reality expressed through sound. There are just too many 


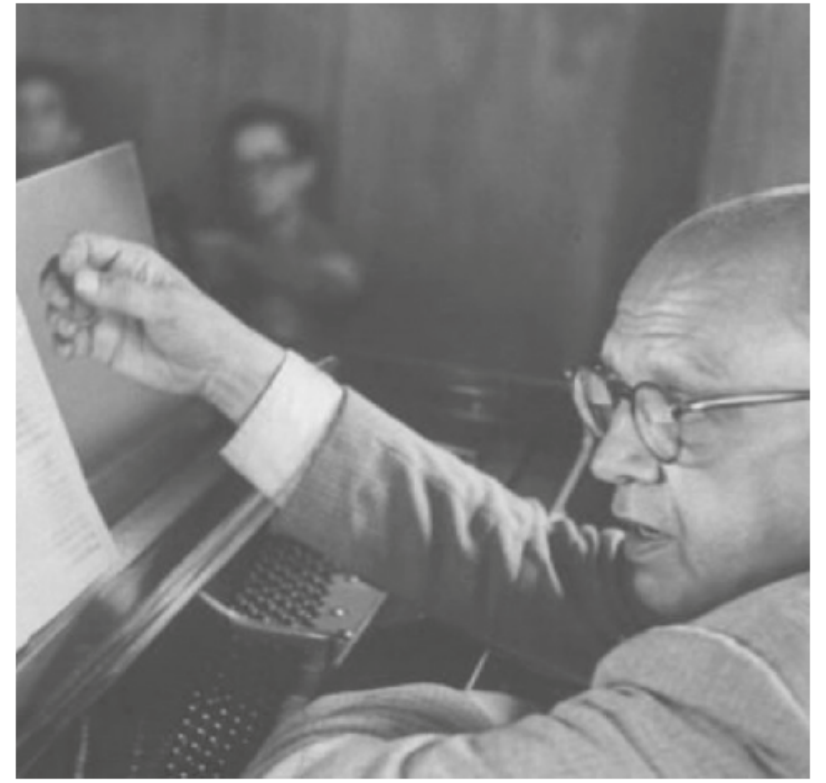

Photo 5. Roger Sessions. Photo by Grey Wilette

verbal clues you give again and again in your scores, emotional clues, to show you feel music is a language of emotions. So-a penny (or a million bucks) for your thoughts!

George Tsontakis: I'll take the million, thank you! I actually composed quite a bit of vocal music, in the form of choral - oratorio when I was starting out, due in large part to the fact that I was conducting choruses, including the Metropolitan Greek Chorale, which held an annual concert with orchestra in Alice Tully Hall. The Chorale commissioned several works from me, almost every year, but they were unwieldy piece, difficult, and difficult to have reprised, and some were in Greek. My intended doctoral "thesis" at Juilliard was an ambitious "Dramatic Oratorio" that I composed with Sessions - my only teacher, by choice, during my four years at the school. The 75 minute work, Scenes from the Apocalypse, was for a Greek "tragic chorus" (speaking or chanting in Koine Greek), soloists, chorus and orchestra.

At the post-premiere reception (of Sessions's Eighth Symphony with the Syracuse Symphony) he introduced me as one "composing a rather remarkable work on the Book of Revelation.” After Sessions tried to get it performed at Juilliard, I told him that the work would never get performed. He insisted that it would but I'm sure I was right. Around that time I was reading Thomas Mann's Dr. Faustus, but got scared halfway through and likewise, never completed a (most likely) two minute passage which was to represent the great battle in Heaven. Because Juilliard would not produce it, I submitted a much shorter work, also a cantata for chorus, narrator and orchestra and biblical in nature, from the Epistle of St. James. That work, as well, was never performed.

Ironically enough, at the time of this writing and after decades of no like idiom, I am back to oratorio style, this time a requiem for the Albany Symphony. I have composed songs and short a capella choral works in the interim, but I would say that, in essence, I'm a "germination composer" at heart--and the germ is usually a short motif or gesture with a lot of the DNA that Rochberg spoke of. In that sense, I'm with Duke. In a talk or lecture I often bring up my personal spiel on "Songs Without Words" and often couple it with "the masses don't listen to music, maybe four percent listen to music, the rest listen to song”, a marriage of words and music (and where to so many, the words are the meaning and the music, the lubricant that the words flow with). But no doubt, song is all of our favorite idiom and have a powerful affect on our daily lives.

At the same time I plead for children to be exposed to pure music, at the propitious time in life (as language is or languages are) in time for them to develop a cognitive relationship with the abstraction made unabstract, through recognition of prolonged repetition and variation. On the other hand, knowing and loving so many songs, I rarely remember the lyrics, except for the title phrase and maybe the chorus.

As for analyzing further, I would just say that I tend to protect my underlying Philosophy of Music by not describing it in 
words, which might well ruin the necessary tension beneath the surface-but in music. For me, that's the whole point. In other words, I'd rather not let the cat out of the bag since I am afraid that the cat might escape and never been seen or heard from again.

Edward Green: Some composers, as you know, seem on the whole to like their pieces to culminate in a blazingly grand, resounding manner. I've notice (correct me if I am wrong) that this is far from your preferred way. It seems, in fact, rare for you. You tend to conclude in a more open or suggestive manner, most of the time. Understated, even. So, am I right? And if I've got this right, would you say this way of ending pieces arises from a gut instinct? Or does it come from a deliberate philosophic decision on your part? Or - perhaps - a combination of gut and deliberation?

George Tsontakis: I would suggest that listeners first finish listening to all of the many thousands of historical "Classical" pieces that end with a predictable bang, and then do the same for the 20th century pieces that end similarly (many do not). Once that process and listening assignment is fulfilled, they should let me know if they still need more works to end in that fashion. Along the way of that listening, they may have encountered works by Debussy and others, that are not only the musical equivalent of the first nonrhyming poetry - that is, free verse, but are truly poetic and generous in allowing the listener to feel when the piece ends.

By far, most of my works end in a "dot, dot, dot" - as I have mentioned many times in many places. That exit strategy allows the memory of the listener to wander back and forth into the piece that was just experienced, instead of having a door of finality slam in their faces (once again, my dream remembrance reference).

Of course, many, especially those imbued with Western Cultural patterns, almost require such finality in the way they are used to dessert following their meal. I only don't need it, I really don't like it and believe that the more open (I don't want to say "unresolved") endings are left, the more mature, sophisticated and progressive they seem. In fact, I can't really say that I end a piece; I leave a piece (and leave open what to think next) to the listener's imagination.

Edward Green: I know that over the years you've written new works almost entirely in response to definite commissions. Perhaps you've already received a commission spurred on by the impact of the pandemic we've been enduring. But I did wonder: have you had thoughts impelled by this global crisis which are making for music in you? Might we have a new composition because of it, commission or no? This being such an exceptional time for all of us, I thought in this regard - in this creative sense - it might prove an exception for you.

George Tsontakis: No, not at all, but to be blatantly honest, if someone came up with a lucrative commission for me to compose a work in sympathy with the pandemic, I would probably accept it and come up with something akin to it. Or I would (like a Method Actor) think of something from my personal past which to me, conjured up the most pathos I could muster. I tend to react to traumatic events, especially universal ones, quite a while after the circumstances are happening, if at all. If so, then after a period of reflection and processing. As it happens, I am supposed to be writing a requiem at the moment, which seems timely enough. But my requiem has not been (in development and creative percolation) this requiem of a global nature. Perhaps my second requiem will be. I remember a teacher mentioning that Schubert wrote his saddest music when he was joyfully happy and his happy stuff when he was in sulking, if not approaching a moribund state. I recently told a friend that I'd much rather be working on an opera buffa than a requiem, to balance the seesaw of (sadness and relief).

Edward Green: Thank you for this engaging interview.

George Tsontakis: You are very welcome.

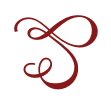




\section{Q SELECTED DISCOGRAPHY $\sim$}

String Quartets Nos. 3 \& 4

Four Symphonic Quartets

New York Variations; Ghost Variations

Piano Quartet (Trilogy)

Heartsounds

Eclipse; Antares

Man of Sorrows

Mirologhia

True Colors (Three concertos)

Sonnets (English Horn concerto)
KOCH (1992)

KOCH (1997)

HYPERION (1998)

$\mathrm{KOCH}(2004)$

$\mathrm{KOCH}(2004)$

INNOVA (2005)

HYPERION (2007)

$\mathrm{KOCH}(2008)$

NAXOS (2015)

NAXOS (2019)

About the author:

Edward Green, Ph.D. (New York University), Composer, Professor in the Department of Music History, Manhattan School of Music (10027, New York City, United States of America)

ORCID: 0000-0002-7643-1187, edgreenmusic@gmail.com

Об авторе:

эдвард Грин, Ph.D. (Нью-Йоркский университет), композитор, профессор кафедры истории музыки Манхэттенской школы музыки (10027, г. Нью-Йорк, Соединённые Штаты Америки), ORCID: 0000-0002-7643-1187, edgreenmusic@gmail.com 